\title{
The International Criminal Court Jurisdiction Towards the Deportation Issues in Myanmar
}

\author{
Bugivia Maharani Setiadji Putri ${ }^{1}$; Sefriani ${ }^{2}$ \\ Faculty of Law, Universitas Islam Indonesia \\ Corresponding author's email: sefriani@uii.ac.id
}

\begin{tabular}{l}
\hline Article Information \\
\hline Submitted : August 10, 2021 \\
Reviewed : October 17, 2021 \\
Revised : Novemver 01, 2021 \\
Accepted : November 14, 2021 \\
Keywords: \\
deportation; human rights; \\
international criminal court; \\
jurisdiction; Rohingya \\
DoI: 10.20961/yustisia. \\
v10i3.54279
\end{tabular}

\begin{abstract}
This research aims to comprehensively analyze the International Criminal Court's jurisdiction in adjudicating gross violations of human rights involving a non-party state of the 1998 Rome Statute and its application to the perpetrators of deportation against the Rohingya with Myanmar as the non-party state. The results showed that this jurisdiction can be implemented under three conditions, first, the crime is committed by nationals of a non-party state on the territory of a state party to the Statute. Second, the UN Security Council refers a situation to the International Criminal Court in its resolution. Third, through an ad hoc declaration that a non-party state of the Rome Statute accepts the International Criminal Court's jurisdiction. Since the territorial jurisdiction of the International Criminal Court covers crimes that occur wholly or partly on the territory of a state party, it can be applied to the deportation against the Rohingya in Myanmar. This involved the fleeing of this ethnic group from attacks by the Government of Myanmar to Bangladesh, a state party to the 1998 Rome Statute.
\end{abstract}

\section{Introduction}

The International Criminal Court (ICC) was established based on the international treaty of the 1998 Rome Statute (hereinafter referred to as the Statute). According to the principle of pacta tertiis nec nocent nec prosunt contained in Article 34 of the Vienna Convention on The Law of Treaties 1969 (VCLT, 1969), an international agreement will not provide obligations for a country without its "consent." Therefore, the authority possessed by ICC to adjudicate under the Statute is limited to countries "consented" or become parties to the Statute (Triyana, 2013). 
Several countries are not parties to the Statute, including Myanmar, where various crimes and discrimination are suspected against the ethnic Rohingya, a Muslim group based in Rakhine, a state on the West Coast of Myanmar. This group constitutes about $35.6 \%$ of Myanmar's population and is estimated to make up half of the country's $15 \%$ Muslim populace. However, Rohingya is not included in the 135 ethnic groups recognized by the country's government, leading to their categorization as stateless people based on the 1982 Myanmar Citizenship Law (Mohajan, 2018).

A person's citizenship status is important, as people without citizenship status often experience various acts of discrimination because they cannot demand protection by national and international law (Sefriani, 2015). In 2013, the United Nations (UN) described ethnic Rohingya as one of the most persecuted minorities in the world. Furthermore, several Human Rights Watch reports (2013) support the existence of crimes against humanity that have occurred since June 2012 as part of the ethnic cleansing campaign against the Muslim population in Arakan State, which includes the Rohingya. The Human Rights Watch (2017) also reported acts of murder, sexual violence, and mass arson in several villages of Rakhine State, which forced this ethnic population to leave their homes. Hence, at least more than 500,000 members of the ethnic Rohingya population in Myanmar have been intentionally deported to the Bangladesh border since August 2017 (OHCHR, 2017).

Based on the discovered elements of the genocide and crimes against humanity, the UN Human Rights Council Facts Finding Mission on Myanmar concluded that several actions by the country's government constituted serious violations of human rights and the International Humanitarian Law (Report of the detailed findings of the Independent International Fact-Finding Mission on Myanmar - A/HRC/39/CRP.2, 2018). Although the crimes of genocide and humanity are 2 of the 4 core crimes stated in the Statute, this does not allow ICC to exercise its jurisdiction, considering Myanmar is not included in the party. Subsequently, the Public Prosecutor proprio motu applied to the ICC Preliminary Session Council in 2018. This concerned the implementation of ICC's jurisdiction under Article 12 paragraph (2) (a) of the Statute concerning deportation, a crime against humanity, committed against the ethnic Rohingya in Myanmar (Prosecution's Request for a Ruling on Jurisdiction under Article 19(3) of the Statute - ICC-RoC46(3)-01/18-1, 2018).

This issue attracted attention, as, besides Myanmar's position as a non-party to the Statute, the crime of deportation against the ethnic Rohingya did not occur in only one area of the country but across national borders. Therefore, this research explores a perspective that differs from several former investigations that discussed ICC's jurisdiction over non-party states of the Statute. The previous research entitled "ICC Jurisdiction against Countries that are not Members of the 1998 Rome Statute" (Sefriani, 2007) only discussed ICC's jurisdiction over countries that are not parties to the Statute, without any separate discussion of their involvement in deportation crimes. Another titled "The Authority of the International Criminal Court (ICC) in Handling Cases of the Rohingya Ethnic Genocide" (Purnama, 2019) showed different forms of crime but 
was limited to genocide. However, this research focuses more on deportation, which is part of the crimes against humanity in the Statute. Also, the investigation discusses ICC's jurisdiction in adjudicating gross human rights violations involving states that are non-parties to the Statute and its exercise against the deportation of the ethnic Rohingya involving Myanmar, a non-party state.

\section{Research Method}

This research used a normative legal method with statutory and conceptual approaches. Secondary sources were used and obtained from primary, secondary, and tertiary legal materials (Soekanto, 2008). The primary legal materials comprised several International Agreements, the secondary materials were books, articles, and legal journals, which are relevant to research, while the tertiary legal materials involved dictionaries for understanding certain terms. Meanwhile, the descriptive qualitative method was employed to analyze factors related to the research object by presenting more in-depth data (Prabowo and Heriyanto, 2013).

\section{Analysis and Discussion}

A. Jurisdiction of the International Criminal Court in Adjudicating Serious Human Rights Violations Involving Non-Parties to the 1998 Rome Statute

ICC's jurisdiction in adjudicating gross human rights violations involving non-parties to the Statute can be viewed from two perspectives. First, the aspect of personality or from viewpoint of the perpetrator, who is a citizen of a nonparty state of the Statute. Second, the territoriality or position of the country where the gross human rights violation occurred.

According to Article 1 of the Statute, the ICC has the power to exercise its jurisdiction over individuals for the most serious international crimes. Article 25 of the Statute also stipulates that this institution has jurisdiction over those who can be held accountable for their crimes, regardless of the position held when it was committed. Therefore, regarding personal jurisdiction, the ICC only applies to individuals, especially citizens of a country party to the Statute, as stated in Article 12 concerning the preconditions for the entering force of the Statute, but not states or other international legal subjects (Parthiana, 2015).

Since this personal jurisdiction can only be exercised in a country that has bound itself to the Statute, it solely applies to citizens of a country party to the Statute. However, according to Bassiouni (2001), a citizen of a non-party to the Statute can be subject to the ICC's jurisdiction by committing a gross violation of human rights in a state party's territory or against its citizen. This is because the preconditions for the ICC jurisdiction, namely the elements of territoriality and personality, which must be fulfilled simultaneously, are not stipulated in Article 12 of the Statute. Hence, the ICC can exercise its jurisdiction, providing one of the preconditional elements in Article 12 is fulfilled. The ICC also explained 
that committing at least one criminal element or the occurrence of the crime consequences in its party state's territory grants it the power to exercise its jurisdiction (The State of Palestine's observations concerning the request for a ruling on the Court's territorial jurisdiction - No. ICC-01/18, 2020).

Therefore, the ICC may implement its jurisdiction over crimes committed in the territory of a party state regardless of the perpetrator's nationality. This can be interpreted as the ICC's application of the territorial jurisdiction principle in its implementation.

Concerning territorial jurisdiction, the Statute explains that ICC's jurisdiction can be exercised over international crimes committed in a state party to the Statute, including on ships or aircrafts registered with that country (Sefriani, 2007). In explaining this jurisdiction, Article 12 paragraph (2) (a) of the Statute used two different terms, namely 'conduct' and 'crimes.' In this case, the Statute did not explain the relationship between the location and consequences of the crime. However, Paul Ardis Jr. (2016) argued that the term 'conduct' is intended to refer to the crime as a whole, while 'crimes' can be related to Article 22 paragraph (1) of the Statute, regarding the perpetrator knowledge that the act is a crime.

Furthermore, the territorial jurisdiction can be extended to non-party states. In the case of a citizen of a non-party state committing a gross human rights violation on the territory of a non-party state, ICC's jurisdiction can be exercised in two ways. First, the submission of the situation through the UN Security Council resolution as contained in Article 13 (b) of the Statute. Second, a declaration from a non-party state to the Statute as stipulated in Article 12 paragraph (3).

Based on Chapter VII of the UN Charter, Article 13(b) allows the UN Security Council to submit the situation to the ICC. This submission was made through a resolution issued by the UN Security Council requesting the Public Prosecutor to examine a situation (Schabas, 2016). In such situations, the UN Security Council first determines the presence of threats to security, violations, or acts of aggression before recommending or determining the actions to be taken in order to maintain international peace and security (Article 39, UN Charter). The submission of related cases through this UN Security Council allows the implementation of ICC's jurisdiction over non-party states of the Statute, regardless of the territoriality or nationality of the perpetrator. This is based on Article 25 of the UN Charter, in which member states agree to accept 
and implement decisions made by the UN Security Council. The decision to file such cases is part of giving ICC the jurisdiction to act under the Statute, especially against non-party states (Akande, 2009). Therefore, the submission of a case through the UN Security Council's resolution to the ICC for review by the Public Prosecutor is binding on all UN member states and may require their cooperation regardless of the country's affiliation with the Statute (Wenqi, 2006)world public attention was focused on issues such as the significance of the Court's establishment, the importance of implementing international criminal justice and the time when the Rome Statute could enter into force. Once the Court was established, attention naturally turned to practical issues, such as whether it would be able to operate normally and perform its historic mission. The question of whether the ICC can operate effectively and perform its mission largely depends on the scope and degree of co-operation provided to it by states. This co-operation concerns not only states party to the ICC but also nonparty states. This article offers to explore the obligation of non-party states to co-operate under international law, the prospects of their co-operation and the legal consequences of non-co-operation. The author suggests that beyond the general principle of the law of treaties according to which treaties are binding only on states parties, when viewed in the light of other general principles of international law, co-operation with the ICC is no longer voluntary in nature, but is instead obligatory in the sense of customary international law. Therefore, the submission of a case through the UN Security Council's resolution to the ICC for review by the Public Prosecutor is binding on all UN member states and may require their cooperation regardless of the country's affiliation with the Statute (Wenqi, 2006). However, the cooperation of non-party states is voluntary, and the ICC can only invite and assist these countries based on an ad hoc agreement (Article 87 paragraph (5) (a)).

Meanwhile, the submission of a case through the UN Security Council has occurred before at ICC. This was on March 31, 2005, when the UN Security Council adopted Resolution Number 1593 and decided to submit the situation in Darfur, Sudan, on July 1, 2002, to the Public Prosecutor_UN Security Council - S/RES/1593, 2005). The UN Security Council resolution also urged the Government of Sudan and other relevant parties to cooperate fully and provide the necessary assistance to the Public Prosecutor and ICC. Although Sudan is not a party to the Statute, it is bound by the provisions of Article 25 of the United Nations charter as a member state of the United Nations and thereby obliged to implement the contents of the Resolution. Furthermore, the rights and obligations of states parties to the Statute in UN Security Council Resolution Number 1593, which applied to Sudan, emerged from the council resolutions and the UN Charter rather than the Statute (Akande, 2009).

Although the UN Security Council resolutions are binding on all United Nations members regardless of their affiliation with the Statute, requiring their cooperation with the ICC, implementation is still ineffective. This is because the decision of the UN Security Council, which is supposed to be a political 
institution with various interests from each member country, can be canceled or rejected by the 5 permanent UN members, namely the United States, Britain, Russia, China, and France, which have veto powers. These countries may reject the Council's resolutions that may be harmful to them (Parthiana, 2015). Also, Al Shraideh (2017) argued that the veto power that should be used to maintain world peace, as well as the goals and principles of the United Nations, is instead used to protect the allies of these 5 five permanent member states.

Besides, using the UN Security Council, Article 12 paragraph (3) of the ICC allows the implementation of its jurisdiction over crimes committed in the territory of a non-party state through a declaration. The article describes a declaration that can allow non-party states to accept the jurisdiction on an ad hoc basis without requiring the concerned nation to agree to the Statute (Eboibi, 2012). The country also determines its willingness to issue a declaration regarding its acceptance of the jurisdiction (Parthiana, 2015).

Meanwhile, some countries that are not parties to the Statute have issued declarations under Article 12 paragraph (3). On April 18, 2003, the Government of the Republic of Côte d'Ivoire issued a declaration to accept ICC's jurisdiction over crimes committed in the country indefinitely from September 19, 2002 (Situation in The Republic of Côte d'Ivoire, Decision pursuant to Article 15 of the Rome Statute on the Authorisation of an Investigation into the Situation in the Republic of Côte d'Ivoire - No. ICC-02/11, 2011). The declaration has a function similar to the self-submission by states parties to the Statute (Bergsmo and Stahn (ed.), 2018). This is explained in Number 44 (2) of the Rules of Procedure and Evidence, which states that the acceptance of ICC's jurisdiction under Article 12 paragraph (3) by a non-party state requires all provisions in the Statute to apply fully against that state as well as the party-state. In addition, Uganda issued a declaration under Article 12 paragraph (3) of the Statute on 27 February 2004 (Decision Assigning the Situation in Uganda to Pre-Trial Chamber II - ICC02/04, 2004). The country ratified the Statute on June 14, 2002, and accepted ICC's jurisdiction over crimes committed since July 1, 2002 (Decision Assigning the Situation in Uganda to Pre-Trial Chamber II - ICC-02/04, 2004). This contrasted with the declaration by the Government of the Republic of Côte d'Ivoire, a nonparty state. Adequately, the purpose of Uganda's issuance was to fill the time gap stated in Article 11 paragraph (2) of the Statute regarding ICC's limited temporal jurisdiction to crimes committed after the entry of the Statute into that country.

From the explanation above, the declaration in Article 12 paragraph (3) of the Statute can be concluded to contain at least 2 important elements (Bergsmo and Stahn (ed.), 2018). First, it allows ICC to exercise its jurisdiction over nonparty states of the Statute by investigating and prosecuting gross human rights violations in such countries. Second, Article 12 paragraph (3) of the Statute is a form of extension of the territorial and personal jurisdiction of the ICC and can also expand the temporal jurisdiction. 


\section{B. Jurisdiction of the International Criminal Court for the Crime of Deportation against the Ethnic Rohingya in Myanmar}

1. Submission of the Situation in Myanmar by the Public Prosecutor proprio motu

In 2018, the Public Prosecutor submitted an application to Article 19 paragraph (3) of the Statute and Rule 46 (3) of the Regulations of the Court (ICC Regulation). This was regarding the exercise of ICC's jurisdiction under Article 12 paragraph (2) (a) of the Statute against the alleged crime of deportation of the Rohingya in Myanmar, which is a crime against humanity. The main request was to ask the Preliminary Session of the Assembly to decide that the ICC has territorial jurisdiction over a crime involving deportation from a non-party country into a state party to the Statute.

Subsequently, the Public Prosecutor's application was based on the difference between deportation, as defined in Article 7 paragraph (1) (d) of the Statute, and forced transfer. The crime of deportation has a requirement that the victim is forced to cross the border from a country to another, either de jure or de facto. Therefore, one element of the crime is resolved in the territory of another country (Prosecution's Request for a Ruling on Jurisdiction under Article 19(3) of the Statute - ICC-RoC46(3)-01/18-1, 2018). Regarding the area or place where the deportation occurred, the Public Prosecutor argued that the interpretation of Article 12 paragraph (2) (a) of the Statute requires that a crime can occur wholly or partly in the territory of a state party to the Statute.

However, the Myanmar Government expressly objected to the Public Prosecutor's request in April 2018, stating that Myanmar is not a party to the Statute and has never declared its approval of the ICC's jurisdiction. The government also considered the efforts made by the Public Prosecutor a violation of Article 34 of the 1969 Vienna Convention and a disregard of state sovereignty and non-intervention contained in the United Nations charter (Annex E to the Prosecution Notice of Documents for Use in Status Conference - ICC-RoC46(3)-01/18-27-AnxE).

At the First Preliminary Session, the ICC decided that it was authorized to determine jurisdictional issues that were part of the Public Prosecutor's application. This decision was based on Article 119 paragraph (1) of the Statute and the principle of international law la compétence de la competence, which allows any international court to exercise its powers and obligations in determining the boundaries of its jurisdiction and competence (Decision on the Prosecution's Request for a Ruling on Jurisdiction under Article 19(3) of the Statute - Number ICC-RoC46(3)-01/18, 2018). It also argued that Myanmar is not a party to the Statute and the case was not brought forward 
through the Public Prosecutor and not the resolutions of the UN Security Council. Subsequently, the Council stated that Article 7 paragraph (1) (d) of the Statute contains two separate crimes, namely forced transfer and deportation, as well the association of one of the deportation elements with another country, Bangladesh. Therefore, the Council declared that ICC's jurisdiction could be exercised in the proposed situation. It also agreed to proceed with a preliminary examination by the Public Prosecutor regarding the alleged crimes committed against the Rohingya people and stipulated the completion within a reasonable time (Decision on the Prosecution's Request for a Ruling on Jurisdiction under Article 19(3) of the Statute Number ICC-RoC46(3)-01/18, 2018).

The Council of the Third Preliminary Session decided that the Public Prosecutor may investigate the deportation and other crimes defined in Article 5 of the Statute that may be discovered during the investigation process. However, it limited this capacity to crimes committed at least partly in the territory of the affiliated state and after the entry of the Statute's force into that state (Situation in the People's Republic of Bangladesh/Republic of the Union of Myanmar - ICC-01/19, 2019).

2. Analysis of the Situation in Myanmar

As stated in Article 15 paragraph (1) of the Statute, the Public Prosecutor is allowed to conduct investigations that can trigger the enforcement of the ICC jurisdiction on a proprio motu basis or of his free will (Klamberg, 2017). Hence, the investigation must be performed based on his interpretation of the law and facts (Roeben, 2003). The Public Prosecutor can also obtain information about a situation from countries, certain organs of the United Nations and other trusted and appropriate sources. However, regarding the situation of the ethnic Rohingya by the Government of Myanmar, which is a non-party state of the Statute, the Public Prosecutor pursuant to Article 19 (3) may request ICC's decision on the jurisdictional issue. This article authorizes the Public Prosecutor to request the ICC's decision on the jurisdiction and admissibility of a situation. In fact, a different case (Prosecution Request pursuant to Article 19 (3) for ruling on the Court's Territorial Jurisdiction in Palestine - ICC-01/18, 2020). 
The publc prosecutor was permitted to request a decision on jurisdiction before the Preliminary Session Council issues a detention order under Article 58 paragraph (3) or a summons based on Article 58 paragraph (7) of the Statute. This is because the ICC's territorial jurisdiction must be fulfilled when the arrest warrant and summons are issued by the Preliminary Session Council. In addition, Number 58 (4) of the Rules of Procedure and Evidence stipulates that jurisdictional issues must be decided first by ICC before the issue of admissibility of a situation.

Therefore, ICC has jurisdiction over gross human rights violations in Myanmar based on several legal arguments. First, it is related to the criminal jurisdiction of ICC in Article 5 of the Statute, which is limited to 4 crimes, namely genocide, crimes against humanity, war crimes, and crimes of aggression. The crime alleged to have occurred in the situation proposed by the Public Prosecutor regarding the exercise of the ICC's jurisdiction is deportation, which is a crime against humanity, as defined in article 7 paragraph (1) (d) of the Statute.

Deportation or the forcible transfer of population, pursuant to Article 7 paragraph (2) (d), is defined as the forced transfer of persons by expulsion or other coercive measures from the area where they legally live without reasons permitted under international law. Although deportation and the forcible transfer of people are closely related to forced and illegal eviction from their area of residence, there are differences between the two in customary international law. First, the transfer referred to in the crime of deportation is executed beyond the territorial limits of a country, while the forcible transfer of population occurs within a country (Prosecutor v. Radislav Krstic - IT-98-33-T, 2001). Also, deportation is considered illegal, providing coercion is involved, including physical force, threat, fear of violence, detention, psychological pressure, abuse of power, or exploiting circumstances that compel the action (Prosecutor v. Milorad Krnojelac - IT97-25-T, 2002). Such conditions can create circumstances where there is no choice but to leave, leading to forced displacement (Prosecutor v. Vlastimir Dordevic - IT-05-87/1-A, 2014).

An interesting note is that the ICTY Ad Hoc Court (Prosecutor v. Milmomir Stakic, - IT-97-24-A, 2006) previously stated that the mens rea of deportation did not require the perpetrator's intention to permanently transfer the victim across the borders of a country. Meanwhile, the actus reus, in a past ICC jurisdiction (Prosecutor v William Ruto et al. - ICC-01/0901/11, 2012), concluded that the perpetrator could commit several different acts that forced the victim to leave their residence. Therefore, proving the occurrence of the crime of deportation necessitates a relationship between the actions and the consequences, namely causing the victim to leave his country of residence for another. 
In several reports from UN organs, such as UNHRC and NonGovernmental Organizations (NGOs), that focus on issues of human rights violations, the Human Rights Watch mentioned various continued attacks in various Rakhine State villages against the Rohingya in Myanmar since 25 August 2017 (HRW, 2017). The attacks were part of the Burmese military campaign and included killings, rapes, arbitrary arrests, and mass house burnings (HRW, 2017). Meanwhile, the Burmese military has a "FourCuts" policy that has operated since 1960 and is aimed at cutting off armed groups' access to food, financial aid, and civilian recruitment. This policy corresponds to the Burmese military clean-up operation and scorched earth campaign, which resulted in the killing of most of the civilians, the destruction of villages, and mass displacement (UNHRC, 2019). Eventually, the majority of the Rohingyas went to Bangladesh, which is the closest country to Myanmar (HRW, 2018). This occurrence indirectly highlights the consequences of the Burmese military policies and actions, which forced the helpless Rohingyas to flee their homes to survive.

The second argument concerns the ICC's territorial jurisdiction, which (2019) described as the principle and head of other jurisdictions. It allows the state to exercise its judicial authority against crimes that occur in its territory regardless of the perpetrator's nationality (Vagias, 2011). Although this is based on Article 12 paragraph (2) (a) that the ICC's jurisdiction is limited to crimes committed in the territorial area of a party state, the Statute article does not explain the scope of the actions further. Meanwhile, based on the theory of ubiquity, which is the development of the territorial jurisdiction principle, a country can exercise its authority over crimes where at least one of the elements, either the crime (subjective territorial jurisdiction) or the result (objective jurisdiction) occurs in its territory (Maillart, 2018). The subjective territorial jurisdiction permits a state to prosecute crimes that begin in their territory but are completed in another country (Vagias, 2011). Conversely, the objective territorial jurisdiction is justified by the continuous action doctrine, which states that a criminal act is considered to persist when consequences still occur in another country (Ilias, 2011). ICC has used these theories to determine the issue of territorial jurisdiction in several of its decisions, including the Afghanistan situation. Here, (Situation in the Islamic Republic of Afghanistan - ICC-02/17, 2019), the acts that were alleged to have occurred wholly or partly on the territory of Afghanistan or other state parties fall within the ICC's jurisdiction, regardless of the perpetrator's nationality. This jurisdiction also applies when an action is completed or initiated in the territory of a party state and continued in a non-party country or vice versa. 
Based on the Elements of Crimes of Article 7 paragraph (1) (d), which requires that the execution or destination of the transfer be conducted in another country, this was one of the aspects of the deportation crime against the ethnic Rohingya. Since its inception in 2017 and 2-year duration, the ethnic cleansing operation has resulted in the flight of at least 743,000 Rohingya people to Bangladesh, a state party to the Statute (UNHCR, 2019). Therefore, ICC has territorial jurisdiction over the situation in Myanmar, especially concerning these transboundary crimes.

The third argument is related to the ICC's temporal jurisdiction, according to Article 11 of the Statute, namely only regarding crimes committed after the entry of ICC into a country. Based on this stipulation and the investigation conducted by the Public Prosecutor, the ICC's jurisdiction is limited to crimes committed after the entry of the Statute's force into Bangladesh in 2010.

Fourth, the admissibility of a proposed situation, where the Statute recognizes the principle of state sovereignty, resulting in the complementary principle, which is one of ICC's basic principles. The ICC was formed as a complement to the national criminal jurisdiction, as stated in the Statute's preamble. According to Wagner (2003), this is a distinguishing factor from previous ad hoc courts, which had concurrent jurisdiction and were superior to national courts. However, the ICC can only exercise its jurisdiction, providing a case is acceptable, meaning the country concerned is neither willing nor able to conduct an investigation or prosecution. Article 17 also explains that a case cannot be accepted after being investigated by the concerned country and the perpetrator's persecution was refused or executed. However, the complementary principle does not affect the jurisdiction of the ICC but regulates situations when its exercise is mandated (Benzing, 2003).

Regarding the admissibility of the Ethnic Rohingya situation, one of the countries can file an objection under Article 1 paragraph (2) (b) of the Statute, supposing it is currently or has conducted an investigation or prosecution. This can be done by Bangladesh based on the principle of territoriality as the country with the jurisdiction, or Myanmar, following the personality principle. However, neither Bangladesh nor Myanmar are currently or have conducted any investigations or prosecutions regarding the situation. Although the case of Myanmar against ethnic Rohingya was previously tried by the ICJ, it was investigated as a genocide, which is different from the submission by the Public Prosecutor at ICC regarding crimes against humanity, specifically deportation.

Therefore, Bangladesh, as a state party to the Statute, is obliged to cooperate with the ICC in the investigation, prosecution, arrest, and 
surrender of the persons concerned. Meanwhile, Myanmar, which is not a party to the Statute, does not have the same obligations, though this does not prevent ICC from exercising jurisdiction over the discussed situation.

\section{Conclusion}

The International Criminal Court has jurisdiction to adjudicate gross human rights violations involving citizens of non-parties of the Statute under three conditions, as follows:

a. The commission of the crime under the jurisdiction of the ICC in the territory of a state party to the Statute. In this case, the Public Prosecutor may file a claim on a proprio motu basis;

b. The UN Security Council, through its resolution in CHAPTER VII of the UN Charter, may propose the examination of a situation by the Public Prosecutor;

c. Non-party states to the Statute can issue a declaration of acceptance of ICC's jurisdiction to conduct investigations and prosecutions of gross human rights violations in their territory on an ad hoc basis.

Concerning Myanmar, a non-party state of the Statute, ICC's jurisdiction can be exercised based on the following legal arguments:

a. One of the elements of the deportation crime is that the transfer is executed in another country. The attacks, which began on August 25, 2017, were part of the Myanmar military campaign and forced the Rohingya to leave their homes. Most of these people fled to Bangladesh, which is the closest country to Myanmar;

b. Bangladesh ratified the 1998 Rome Statute on 23 March 2010 and entered into the Statute's force on 1 June 2010;

c. The definition of territorial jurisdiction in Article 12 paragraph (2) (a) covers crimes, including the action and the consequences, that wholly or partly occur in the territory of a state party to the Statute.

\section{Bibliography}

Akande, Dapo. (2009). The Legal Nature of Security Council Referrals to the ICC and its Impact on Al Bashir's Immunities. Journal of International Criminal Justice, 7.

Al Shraideh, Saleh. (2017). The Security Council's Veto in The Balance. Journal of Law, Policy, and Globalization. (Vol. 58).

Annex E to the Prosecution Notice of Documents for Use in Status Conference -ICCRoC46(3)-01/18-27-AnxE

Ardis Jr., Dennis Paul. (2016). How Much Is Enough? The ICC's Territorial Reach Over Cross Border Crimes. North Carolina Journal of International Law. (Vol. 41). 
Bantekas, Ilias. (2011). Criminal Jurisdiction of States under International Law. Oxford Public International Law.

Bassiouni, M.C. (2001). Universal Jurisdiction for International Crimes: Historical Perspectives and Contemporary Practice. Virginia Journal of International Law. (Vol. 42 No. 1).

Benzing, Markus. (2003). The Complementarity Regime of the International Criminal Court: International Criminal Justice between State Sovereignty and the Fight Against Impunity. Max Planck Yearbook of United Nations Law. (Vol. 7).

Bergsmo, Morten dan Carsten Stahn (ed). (2018). Quality Control in Preliminary Examination: Vol. 2. Torkel Opsahl Academic EPublisher.

Eboibi, Felix E. (2012). Jurisdiction of the International Criminal Court: Analysis, Loopholes and Challenges. Nnamdi Azikiwe University Journal of International Law and Jurisprudence. (Vol. 3).

Galand, Alexandre. (2019). Chapter 1 Conceptions of Courts and Their Jurisdiction in UN Security Council Referrals to the International Criminal Court. Brill. (Leiden Studies on the Frontiers of International Law, Vol. 5).

Human Rights Watch (2018). "Bangladesh is Not My Country" Stateless Rohingya Refugees Expelled from Myanmar. https://www.hrw.org/report/2018/08/05/bangladeshnot-my-country/plight-rohingya-refugees-myanmar

Human Rights Watch. (2013). "All you can do is pray" Crime Against Humanity and Ethnic Cleansing of Rohingya Muslims in Burma's Arakan State. https://www.hrw.org/ report/2013/04/22/all-you-can-do-pray/crimes-against-humanity-and-ethniccleansing-rohingya-muslims

Human Rights Watch. (2017). "All My Body was Pain" Sexual Violence against Rohingya Women and Girls in Burma. https://www.hrw.org/report/2017/11/16/all-mybody-was-pain/sexual-violence-against-rohingya-women-and-girls-burma

Human Rights Watch. (2017). Crimes against Humanity by Burmese Security Forces Against the Rohingya Muslim Population in Northern Rakhine State since August 25, 2017. https://www.hrw.org/news/2017/09/25/crimes-against-humanity-burmesesecurity-forces-against-rohingya-muslim-population

ICC, Decision Assigning the Situation in Uganda to Pre-Trial Chamber II - (ICC-02/04)

ICC, Decision on the Prosecution's Request for a Ruling on Jurisdiction under Article 19(3) of the Statute (No. ICC-RoC46(3)-01/18), PTC I

ICC, Prosecution Request Pursuant to Article 19 (3) for ruling on the Court's Territorial Jurisdiction in Palestine (ICC-01/18), PTC I

ICC, Prosecutor v. William Ruto et al (ICC-01/09-01/11), PTC II 
ICC, Situation in the Islamic Republic of Afghanistan, Decision pursuant to article 15 of the Rome Statute on the Authorisation of an investigation into the situation in the Islamic Republic of Afghanistan (ICC-02/17), PTC II

ICC, Situation in the People's Republic of Bangladesh/Republic of the Union of Myanmar (ICC01/19), PTC III

ICC, Situation in the Republic of Côte d'Ivoire, Decision Pursuant to Article 15 of the Rome Statute on the Authorisation of an Investigation into the Situation in the Republic of Côte d'Ivoire (No. ICC-02/11), PTC III.

ICC, Situation in the State of Palestine, the State of Palestine's observations in relation to the request for a ruling on the Court's territorial jurisdiction in Palestine (No. ICC-01/18), PTC I.

ICTY, Prosecutor v. Milmomir Stakic, (IT-97-24-A), Appeals Chamber Judgement

ICTY, Prosecutor v. Milorad Krnojelac, (IT-97-25-T), Trial Chamber II Judgement

ICTY, Prosecutor v. Radislav Krstic, (IT-98-33-T), Trial Chamber Judgement

ICTY, Prosecutor v. Vlastimir Dordevic, (IT-05-87/1-A), Appeals Chamber Judgement

Klamberg, Mark (ed.). (2017). Commentary on the Law of the International Criminal Court. Torkel Opsahl Academic EPublisher Brussels.

Maillart, Jean-Baptiste. (2018). The Limits of Subjective Territorial Jurisdiction in the Context of Cybercrime. Springer.

Mohajan, Haradhan Kumar. (2018). History of Rakhine State and the Origin of the Rohingya Muslims. IKAT: The Indonesian Journal of Southeast Asian Studies. (Vol. 2 No.1), pp. 19-46.

Parthiana, I Wayan. (2015). Hukum Pidana Internasional. Bandung: CV. Yrama Widya.

Prabowo, Aan and Heriyanto. (2013). Analisis Pemanfaat Buku Elektronik (E-Book) oleh Pemustaka di Perpustakaan SMA Negeri 1 Semarang. Jurnal Ilmu Perpustakaan. (Vol. 2 No. 2) pp. 152-161.

Prosecution's Request for a Ruling on Jurisdiction under Article 19(3) of the Statute (ICCRoC46(3)-01/18-1)

Purnama, Yandhy Chanigia. (2019). Kewenangan International Criminal Court (ICC) dalam Menangani Kasus Genosida Etnis Rohingya. Universitas Kristen Satya Wacana.

Roeben, Volker. (2003). The Procedure of the ICC: Status and Function of the Prosecutor. Max Planck Yearbook of United Nations Law. (Vol. 7, Issue 1).

Rules Procedure and Evidence International Criminal Court

Schabas, William A. (2016). The International Criminal Court: A Commentary on the Rome Statute (2nd ed.). Oxford: Oxford University Press. 
Sefriani. (2007). Yurisdiksi ICC terhadap Negara non Anggota Statuta. Jurnal Hukum. (Vol. 14 No. 2).

Sefriani. (2015). The Efforts to Terminate the Situation with No-Citizenship and Human Rights Violation of Rohingya Ethnic. Journal of Dinamika Hukum. (Vol. 15 No. 1).

Soekanto, Soerjono. (2008). Pengantar Penelitian Hukum. Jakarta: UI Press.

Statuta Roma 1998

Triyana, Heribertus Jaka. (2013). The Significance of the Complementarity Principle Within the Rome Statute in International Criminal Law. Mimbar Hukum. (Vol. 25, No. 3).

UN Charter

United Nations Human Rights Council, Detailed findings of the Independent International FactFinding Mission on Myanmar - A/HRC/42/CRP.5, 16 September 2019.

United Nations Human Rights Council, Mission Report of OHCHR rapid response mission to Cox Bazar, Bangladesh, September 2017.

United Nations Human Rights Council, Report of the detailed findings of the Independent International Fact-Finding Mission on Myanmar - A/HRC/39/CRP.2, 17 September 2018.

United Nations Human Rights Council, The Economic Interests of the Myanmar Military, Independent International Fact-Finding Mission on Myanmar -A/HRC/42/CRP.3, 5 Agustus 2019.

UNSC Resolution No. 1593 (S/RES/1593), 2005.

Vagias, M. (2011). The Territorial Jurisdiction of the International Criminal Court: Certain Contested Issues. Bynkers Hoek Publishing.

Wagner, Markus. (2003). The ICC and its Jurisdiction - Myths, Misperceptions, and Realities. Max Planck Yearbook of United Nations Law. (Vol. 7).

Wenqi, Zhu. (2006). On Co-Operation by States Not Party to The International Criminal Court. International Review of The Red Cross, (Vol. 88, No. 861). 